\title{
Growing Condition and Varietal Impact on Growth Performance and Yield of Yard Long Bean (Vigna unguiculata) Varieties Cultivated under Tropical Climate
}

Laurence Shiva Sundar, Asneel Ashesh Lal, Josphine Sandya Venkataiya Kumar

10.18805/LRF-649

\begin{abstract}
Background: Yard-long bean is one of the exporting crops of Fiji, with approximately half a ton exported annually. Lack of information on the varietal performance under the field condition walls the ability of farmers to choose a suitable variety for higher production under different growing conditions. Therefore, this study aims to identify a higher-yielding variety of yard-long bean that performs to the maximum under the tropical climate of Fiji.

Methods: Three varieties of yard-long bean were selected based on their availability and were planted under three different growing conditions. The data on the chlorophyll content, stem girth, plant height, pod number, pod length and pod weight were collected and analyzed.

Result: The experiment results indicate that the JS15P variety of yard long bean had significantly the highest leaf chlorophyll content in Trial 1 and Trial 2; however, no significant differences were observed in Trial 3 among the three varieties. No significant differences were observed in the stem girth among the three varieties. As for the plant height, the JS15P variety had significantly the highest among the other two varieties. The results also indicated that the JS15P variety of yard-long bean had significantly the highest yield in all three trials; therefore, the JS15P variety of yard-long bean is highly recommended to farmers in Fiji or those cultivating crops under tropical climatic conditions.
\end{abstract}

Key words: Growing condition, Higher yield, JS15P variety, Varietal performance, Yard-long bean.

\section{INTRODUCTION}

The current world population stands around 7.7 billion people, which will likely increase to about 9.7 billion people by 2050 (United Nations, 2019). Such a rapid increase in the world population means that world food production needs to be drastically increased by 2050 (Godfray et al., 2010; Nastis et al., 2012). The production of crops in the coming years will be much stressful as climate change is expected to have a negative effect on crop yields (Sundar and Chen, 2020). The agricultural productivity will be directly impacted by the changes in the intensity and frequency of rainfall and extreme weather events, higher temperature and increased $\mathrm{CO}_{2}$ concentration for photosynthesis (Nastis et al., 2012). The agricultural sector of the countries in the tropical and sub-tropical regions will be experiencing higher consequences of climate change resulting in a direct impact on their marginal water balance (Lemi and Hailu, 2019).

Agriculture is the third-largest industry in Fiji that engages around $70 \%$ of the population, mainly subsistence, semi-subsistence and commercial agriculture (Ministry of Communication, 2021). Changes in the weather pattern can be a real threat to the agriculture sector in Fiji. Within ten years, the main island's (Viti Levu) central division has recorded an increase in the temperature to about $0.15^{\circ} \mathrm{C}$ and about $0.04^{\circ} \mathrm{C}$ on the western side, thus leading to an increase in hot days and warm nights and a decline in cooler weather (Fiji Meteorological Service, 2015). All these problems affect the overall performance of crops in the field,
College of Agriculture, Fisheries and Forestry, Fiji National University, Koronivia Campus, Fiji.

Corresponding Author: Laurence Shiva Sundar, College of Agriculture, Fisheries and Forestry, Fiji National University, Koronivia Campus, Fiji. Email: laurenceshivasundar@gmail.com

How to cite this article: Sundar, L.S., Lal, A.A. and Kumar, J.S.V. (2022). Growing Condition and Varietal Impact on Growth Performance and Yield of Yard Long Bean (Vigna unguiculata) Varieties Cultivated under Tropical Climate. Legume Research. 45(1): 39-45. DOI: 10.18805/LRF-649.

Submitted: 25-08-2021 Accepted: 27-10-2021 Online: 07-11-2021

thus lowering their productivity. Therefore, thorough research is needed to investigate suitable crop varieties that can withstand these changes in environmental conditions with the potential of providing a higher yield.

The yard-long bean is one of the export crops of Fiji, with approximately half a ton exported annually. Yard-long bean is an annual legume crop that belongs to the Leguminaceae family that originated from southwest China (Suma et al., 2021). It is a summer crop that grows well up to 1500 m elevation and needs weekly irrigation or 4-6 days intervals depending on the weather condition (Rana and Yadav, 2018). The young, immature pods are very lowcalorie vegetables containing larger quantities of soluble and insoluble fibers. Yard-long bean contain a good amount of vitamin $\mathrm{C}$, an excellent amount of vitamin $\mathrm{A}$ and an average 
amount of minerals (Suma et al., 2021) such as iron, copper, manganese, calcium and magnesium (Sakthivel et al., 2020). The plant grows well with a maximum yield, provided the environmental conditions are favorable-however, the overall plant performance and yield are drastically lower under unfavorable weather conditions. Therefore, to understand the growth performances of crops, a growth analysis is performed.

Growth is defined as an irreversible increase in the weight or size of an organism due to an increase in the number and size of the cell (Sheaffer and Moncada, 2011). Growth analysis is still the most accessible and accurate way to evaluate plant growth and the contribution of physiological processes to plant behavior (Schneider et al., 2018). Development to analyze crop growth has provided a better understanding of the growth processes and yield limitations (Brown, 1984). Different growth analysis methods are introduced, which can be used to investigate plants' growth (Anten and Ackerly, 2001). These include the plant's total dry mass, leaf area index, relative growth rate, absolute growth rate and net assimilation rate (Fraile-Robayo et al., 2017). Other growth analysis methods include leaf number, culture growth rate, net assimilation rate, specific foliar area, foliar area ratio and foliar weight ratio (Schneider et al., 2018). Plant growth and partitioning of biomass to marketable parts of plants determine crop yield (Fageria et al., 2010). Temperature is a primary factor in determining the growth and development of plants (Sheaffer and Moncada, 2011) and is the only factor that determines the post-harvest quality of green leafy vegetables (Cantwell and Kasmire, 2002).

Warmer temperatures are expected with climate change and the potential for more extreme temperature events will impact plant productivity (Hatfield and Prueger, 2015). Witnessing the current issues of crop production and the importance of yard-long bean to Fiji's export market, the present study focuses on investigating a suitable yard-long bean variety among the three readily available varieties in Fiji. The variety with the maximum growth and higher yield under the changing weather conditions will be recommended to farmers to increase their overall productivity and profitability, thus improving their livelihood.

\section{MATERIALS AND METHODS}

\section{Study location}

The study was carried out at the Instructional Agricultural Crop Farm (IACF) of the Fiji National University (FNU), College of Agriculture, Fisheries and Forestry (CAFF), Koronivia, Campus, from February to June 2021. The farm is located at an altitude of $6 \mathrm{~m}$ above sea level with coordinates of $18^{\circ} 02^{\prime} 44^{\prime \prime} \mathrm{S}$ and $178^{\circ} 31^{\prime} 55^{\prime \prime} \mathrm{E}$. It is situated about $2.9 \mathrm{~km}$ from Nausori Town and has an average temperature of $28^{\circ} \mathrm{C}$ to $30^{\circ} \mathrm{C}$. Located on the leeward side of Viti Levu, the area receives an annual rainfall of $2000 \mathrm{~mm}$. The climatic conditions are often warm and humid depending on the weather patterns, usually warm during the dry season to very cold in the wet season (Nausori Town Council, 2021).

\section{Experimental design and setup}

A 2-factor experiment was set up in a randomized complete block design (RCBD) with four replications. Factor one was the growing season and the second factor was the variety. Twelve plots were prepared, with each plot having an area of $4 \mathrm{~m}^{2}$ (1 $\mathrm{m}$ in width and $4 \mathrm{~m}$ in length). The vegetable seedlings and the fertilizers were purchased from HOP TIY and Co. Pte Ltd. Dark Green CLS614 (DG14), Jin Shan CLS615P (JS15P) and Dark Green CSR024P (DG24P) variety of yard-long bean (Vigna unguiculata) were used for this experiment. In each plot, two rows of crops were grown with a row spacing of $50 \mathrm{~cm}$ and plant to plant spacing of 30 $\mathrm{cm}$. In each row, there were 12 plants, making it 24 plants in each plot.

\section{Weather data}

The weather data were collected from the Agrometeorology Station at the Instructional Agricultural-Farm Complex of the FNU-CAFF. Daily maximum and minimum environment temperature, relative humidity, sunshine hours, average and maximum wind speed, rainfall and evaporation rate were recorded. To get accurate results, the collected data were cross-checked with the meteorological data provided by the Fiji Ministry of Agriculture, Koronivia Research Station. These data were then recorded in Exce| ${ }^{\circledR} 2019$ and were used to carry out daily management practices.

\section{Soil sample collection and analysis}

Five soil samples were taken to a depth of 0-200 mm using a soil auger. The sampling was done per plot and then mixed to make a composite soil sample before analyses. The results were sent to the Fiji Agricultural Chemistry Laboratory, Koronivia Research Station, for analysis. The results indicated that the average soil has low organic matter content, excessive level of plant-available phosphorus and excessive level of calcium and magnesium, as shown in Table 1.

Based on the results obtained, the experimental plots were prepared using $2 \mathrm{~kg}$ of poultry manure per plot (10 t/ha) two weeks before sowing, as recommended by the Ministry of Agriculture in Fiji. The nutrients required to correct the deficiencies were $161 \mathrm{~kg} / \mathrm{ha}$ of phosphorous, $95.3 \mathrm{~kg} / \mathrm{ha}$ of potassium, $5500 \mathrm{~kg} / \mathrm{ha}$ of calcium, $940 \mathrm{~kg} / \mathrm{ha}$ of magnesium and $110 \mathrm{~kg} / \mathrm{ha}$ of nitrogen.

Since single superphosphate (SSP) contains $12 \%$ sulfur (S), $19 \% \mathrm{P}$ and $21 \% \mathrm{Ca}$; therefore, $409 \mathrm{~kg} / \mathrm{ha}$ of total superphosphate (TSP) or $970 \mathrm{~kg}$ of SSP were recommended as basal application. Sulfate of potash (SOP) contains $50 \% \mathrm{~K}$ and $18 \% \mathrm{~S}$; therefore, $210 \mathrm{~kg} / \mathrm{ha}$ of SOP or $161 \mathrm{~kg} / \mathrm{ha}$ of muriatic of potash (MoP) were recommended. Urea which contains $46 \%$ of $\mathrm{N}$, was recommended at $240 \mathrm{~kg} / \mathrm{ha}$ as a split application. Lime at $1 \mathrm{t} / \mathrm{ha}$ and organic matter at 8-10 $\mathrm{kg} / \mathrm{h}$ a were recommended for application, as shown in Table 2. 
Growing Condition and Varietal Impact on Growth Performance and Yield of Yard Long Bean (Vigna unguiculata) Varieties...

Table 1: Analyzed results of soil samples as obtained from the Fiji Agricultural Chemistry Laboratory, Koronivia Research Station.

\begin{tabular}{lcccccrr}
\hline $\begin{array}{l}\mathrm{pH} \\
(\text { water })\end{array}$ & $\begin{array}{c}\mathrm{EC} \\
(\mathrm{mS} / \mathrm{cm})\end{array}$ & $\begin{array}{c}\text { Total C } \\
(\%)\end{array}$ & $\begin{array}{c}\text { Total } \mathrm{N} \\
(\%)\end{array}$ & $\begin{array}{c}\text { Olsen } \\
\text { Available } \mathrm{P} \\
(\mathrm{mg} / \mathrm{kg})\end{array}$ & $\mathrm{K}$ & \multicolumn{2}{c}{$\begin{array}{c}\text { Exchangeable } \\
\mathrm{Ca} \\
(\mathrm{me} / 100 \mathrm{~g})\end{array}$} \\
\hline 5.8 & 0.07 & 1.30 & 0.09 & 114 & 0.48 & 23.8 & 6.74 \\
\hline
\end{tabular}

Note: Results are reported oven-dried basis.

To convert me/100g to $\mathrm{mg} / \mathrm{kg}$, multiply results by the following factor: Ca by $200, \mathrm{Mg}$ by $122, \mathrm{~K}$ by 391 and $\mathrm{Na}$ by 230 .

pH- Potential of hydrogen; EC- Electrical conductivity; C- Carbon; N- Nitrogen; P- Phosphorus; K- Potassium; Ca- Calcium; Mg- Magnesium.

\section{Harvesting and measurements}

Harvesting was done 30 days after sowing (DAS), DAS 40, DAS 50, DAS 60 and DAS 70. Four samples of each crop from each plot were randomly selected every 10 days after 30 days of sowing, making 16 samples for each crop, with 48 samples harvested and analyzed every 10 days until DAS 70. The plant height and pod length were recorded using a flexible measuring tape, while the stem girth was taken using the vernier caliper. The pods were weighed using the top-loading balance (Shimadzu UX6200H, Shimadzu Corporation, Kyoto, Japan) with an accuracy of $0.001 \mathrm{~g}$. The soil plant analysis development (SPAD) 502 chlorophyll meter (Konica Minolta, Inc., Japan) was used to measure the chlorophyll content of the three newly matured leaves of each sample. The meter was inserted at the maximum sliding depth of $2 \mathrm{~cm}$ in the leaf for consistent results. Readings were carefully taken to avoid leaves getting damaged.

\section{Statistical analysis}

The collected results were subjected to a two-way analysis of variance (ANOVA) using International Business Machines SPSS statistics for Windows, version 26 (International Business Machines Corporation, Armonk, NY, USA). The effects of the different growing seasons and the varietal effects were analyzed. The mean separation was performed within each crop using Duncan's multiple range test at $p=0.05$. All the results were expressed as means \pm standard error. The graphs and charts were produced using Microsoft Excel ${ }^{\circledR} 2019$ (Microsoft Corporation, Washington, DC, USA) and Origin 2021 software (Origin Lab Corporation., Northampton, MA, USA).

\section{RESULTS AND DISCUSSION}

\section{Growing environment condition}

The environmental temperature was affected by the growing season in which the crop was grown. The average temperature in Trial 1 (wet season) was $26.2^{\circ} \mathrm{C}$, which was lower in Trial 2 (wet-dry season) to $25.9^{\circ} \mathrm{C}$. The temperature continued to decrease in Trial 3 (dry season) to $25.0^{\circ} \mathrm{C}$. The highest temperature was recorded in Trial $1\left(29.0^{\circ} \mathrm{C}\right)$ at DAS 12 , followed by Trial $2\left(28.0^{\circ} \mathrm{C}\right)$ at DAS 13 and DAS 14 and Trial $3\left(27.7^{\circ} \mathrm{C}\right)$ at DAS 8 , as shown in Fig $1 \mathrm{a}$. The coolest temperature was recorded in Trial $3\left(21.8^{\circ} \mathrm{C}\right)$ at DAS 46 , followed by Trial $2\left(22.0^{\circ} \mathrm{C}\right)$ at DAS 67 and Trial $1\left(24.3^{\circ} \mathrm{C}\right)$
Table 2: Fertilizer recommendation with a $10 \%$ allowance for leaching and soil maintenance.

\begin{tabular}{ll}
\hline Fertilizer required & Recommendation application rate \\
\hline Phosphate & $\begin{array}{l}\text { TSP at } 409 \mathrm{~kg} / \mathrm{ha} \text { or SSP at } 970 \mathrm{~kg} / \mathrm{ha} \text { as } \\
\text { basal application. }\end{array}$ \\
Potash & $\mathrm{SOP}$ at $210 \mathrm{~kg} / \mathrm{ha}$ or Mop $161 \mathrm{~kg} / \mathrm{ha}$. \\
Lime $(\mathrm{pH})$ & $\mathrm{CaCO}_{3}$ at $1 \mathrm{t} / \mathrm{ha}$ at $4-6$ weeks prior to planting. \\
Urea & $240 \mathrm{~kg} / \mathrm{ha}$ as a split application. \\
Organic matter & $8-10$ t/ha of poultry manure or other organic \\
& materials (mulch) supplemented with chemical \\
& fertilizers to improve soil conditions and \\
& soil biology. \\
\hline
\end{tabular}

at DAS 34. There was not much variation in the daily average temperature throughout the trials, except for Trial 3, which recorded the lowest from DAS 39 and onwards, as shown in Fig $1 \mathrm{a}$.

The relative humidity responded well to the environment temperature throughout the trials. The average relative humidity in Trial 1 was $82.1 \%$ which was increased in Trial 2 to $83.8 \%$. The relative humidity was further increased in Trial 3 to $83.9 \%$, as shown in Fig $1 \mathrm{~b}$. The maximum relative humidity was $99.0 \%$ which was recorded in all three Trials. The lowest relative humidity was recorded in Trial $3(59.0 \%)$ at DAS 59 , followed by Trial $1(63.0 \%)$ at DAS 12 and Trial $2(65.0 \%)$ at DAS 54. There was not much variation observed throughout the trials except for Trial 3, which recorded the lowest relative humidity at DAS 56 and DAS 70, as shown in Fig $1 \mathrm{~b}$.

\section{Leaf chlorophyll content}

Nitrogen is an important mineral element in plants that are mainly found in molecules such as chlorophyll, proteins, amino acids and nucleic acids (Islam et al., 2016). Therefore, one way to determine the nitrogen content in plants is to determine the chlorophyll content in leaves (Bausch and Diker, 2001; Fontes and de Araujo, 2006; Peng et al., 1996; Piekielek et al., 1995). Besides, chlorophyll is an essential photosynthetic pigment used to determine the photosynthetic capacity and hence plant growth (Li et al., 2018). The handheld soil plant analysis development (SPAD) chlorophyll meter is an excellent instrument to determine the chlorophyll and nitrogen status of various crops nondestructively (Fiorentini et al., 2019; Xiong et al., 2015).

The experiment results indicate that the leaf chlorophyll content of the JS15P variety in Trial 1 was significantly 


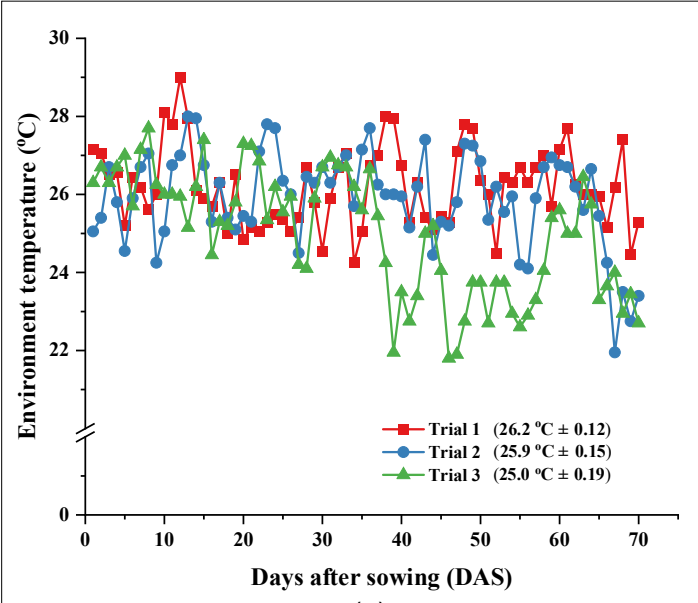

(a)

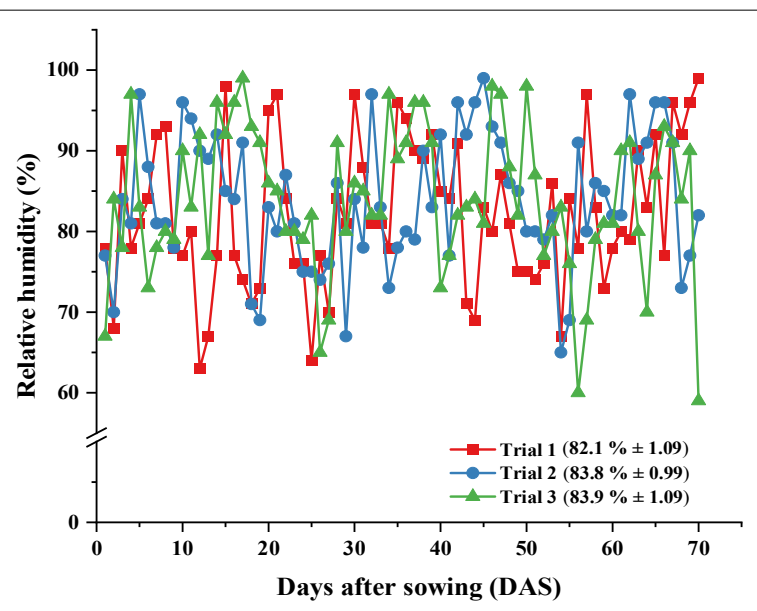

(b)

Fig 1: The environmental temperature and relative humidity recorded throughout the experiment: (a) The average environment temperature recorded in each trial; (b) The average relative humidity recorded in each trial.

Values in parentheses are mean \pm standard error $(n=70)$.

greater than that of DG14 and DG24P. No significant differences in the leaf chlorophyll content of DG24P and DG14 were observed, as shown in Table 3. In Trial 2, both JS15P and DG24P had a significantly higher leaf chlorophyll content than DG14. However, in Trial 3, no significant differences in the leaf chlorophyll content were observed among the three varieties of yard long bean, as shown in Table 3.

The two-way ANOVA results indicated no significant effects of growing conditions on the leaf chlorophyll content of the yard-long bean; however, genotype significantly affected the leaf chlorophyll content. An interaction between growing condition and the genotype had no significant effect on the leaf chlorophyll content of the three varieties of yard long bean, as shown in Table 3 .

The experiment result indicates little to no differences in the chlorophyll content of the yard-long bean cultivated in each trial, especially in Trial 3 , or when compared among each trial. Therefore, the results indicate that the plant nitrogen content was equal in each trial for each variety. The results also indicate little to no differences in the growth of the plants cultivated in each trial.

\section{Plant growth}

To further determine the plant's growth, the yard-long bean's stem girth and plant height data were collected (Attia and Sary, 2021; Dharmawan et al., 2021; Eboibi et al., 2018; Raihan et al., 2021; Sharma et al., 2021). The secondary growth of a plant is characterized by an increase in the thickness or circumference of the stems. In Trial 1, no significant differences in the girth of the plant were observed among the three varieties of yard long bean. Similar results were observed in Trial 2 as well as in Trial 3. The two-way ANOVA results indicate that neither growing condition nor genotype significantly affected the yard-long bean cultivated in each trial. The results also specified that the interaction between growing environment and genotypes had no significant effect on the stem girth of the three varieties of yard long bean, as shown in Table 3 . The results of this experiment indicate that the stem circumference of all three varieties of yard-long bean showed no significant differences within each trial.

As indicated earlier, plant height can also be determining factor for plant growth (Rai et al., 2020). The plant height of yard-long bean in Trial 1, Trial 2 and Trial 3 was significantly the highest in the JS15P variety than DG14 and DG24P. No significant differences in the plant height of DG14 and DG24P were observed, as shown in Table 3 . The results indicated that the JS15P variety of yard-long bean had the highest in all three trials, while no significant differences in the plant height of DG14 and DG24P were observed. The two-way ANOVA results indicate that the growing condition did not significantly affect the plant height of the yard-long bean; however, the genotype had a significant effect on the plant height throughout the trials. An interaction between growing condition and genotype had no significant impact on the height of the plant, as shown in Table 3.

\section{Yield and yield attribute}

The yield of the three varieties of the yard-long bean was determined by the pod number, pod length and pod weight (Attia and Sary, 2021; Raihan et al., 2021). The results of Trial 1, Trial 2 and Trial 3 indicate that the pod number was significantly the highest in the JS15P variety of yard-long bean. At the same time, no significant differences were observed in the pod number among the DG14 and DG24P varieties of yard long bean. The results of this experiment indicate that the JS15P variety of yard-long bean had the highest pod number in all three trials compared to the other two varieties. The two-way ANOVA results indicate that the growing condition and genotype significantly affected the number of pods in all three varieties of yard long bean. However, the interaction between the growing condition 
and the genotype had no significant effect on the number of pods for each of these varieties of yard long bean, as shown in Table 4.

A decline in the number of pods in all three varieties was observed with changes in the growing season. In the wet season, the highest number of pods were harvested, which lowered in the wet-dry season and a further decline in the number of pods was seen in the dry season. The decline in the pod number could be due to the changes in the environment temperature, as shown in Fig 1. The optimum temperature for growing yard-long bean is around $25-30^{\circ} \mathrm{C}$ (Rana and Yadav, 2018). However, in this experiment, a gradual drop in the temperature was seen in Trial 2 and Trial 3, which was below the optimum level. The two-way ANOVA results (Table 4) also indicated that this could be due to the changes in the growing condition.

Table 3: Chlorophyll content (SPAD Value), stem girth $(\mathrm{mm})$ and plant height $(\mathrm{cm})$ of three different varieties of yard long bean grown under different growing conditions.

\begin{tabular}{|c|c|c|c|}
\hline & Chlorophyll content & Stem girth & Plant height \\
\hline \multicolumn{4}{|c|}{ Wet season } \\
\hline Dark Green CLS614 & $49.0 \pm 1.60^{b}$ & $5.42 \pm 0.46^{\mathrm{a}}$ & $273 \pm 19.4^{b}$ \\
\hline Jin Shan CLS615P & $56.2 \pm 1.51^{\mathrm{a}}$ & $6.14 \pm 0.43^{\mathrm{a}}$ & $366 \pm 21.7^{a}$ \\
\hline Dark Green CSR024P & $49.5 \pm 0.98^{b}$ & $5.68 \pm 0.56^{\mathrm{a}}$ & $227 \pm 24.6^{b}$ \\
\hline \multicolumn{4}{|c|}{ Wet-dry season } \\
\hline Dark Green CLS614 & $46.2 \pm 0.91^{\mathrm{b}}$ & $5.67 \pm 0.54^{a}$ & $262 \pm 18.8^{b}$ \\
\hline Jin Shan CLS615P & $50.8 \pm 0.60^{a}$ & $6.39 \pm 0.60^{\mathrm{a}}$ & $360 \pm 18.3^{a}$ \\
\hline Dark Green CSR024P & $50.8 \pm 0.79^{a}$ & $5.73 \pm 0.62^{\mathrm{a}}$ & $249 \pm 14.9^{b}$ \\
\hline \multicolumn{4}{|c|}{ Dry season } \\
\hline Dark Green CLS614 & $50.2 \pm 0.83^{a}$ & $5.04 \pm 0.37^{a}$ & $268 \pm 18.9^{b}$ \\
\hline Jin Shan CLS615P & $52.8 \pm 2.40^{\mathrm{a}}$ & $6.31 \pm 0.39^{a}$ & $363 \pm 19.9^{a}$ \\
\hline Dark Green CSR024P & $50.9 \pm 0.75^{a}$ & $5.09 \pm 0.47^{\mathrm{a}}$ & $238 \pm 18.6^{b}$ \\
\hline \multicolumn{4}{|c|}{ Significance } \\
\hline Growing condition (GC) & ns & ns & ns \\
\hline Genotype (G) & $* * *$ & ns & *** \\
\hline $\mathrm{GC} \times \mathrm{G}$ & ns & ns & ns \\
\hline
\end{tabular}

Values are mean \pm SE $(n=15)$.

Means in the same column, followed by a different letter(s), are significantly different $(p \leq 0.05)$.

${ }^{* * *}=p<0.001 ;{ }^{* *}=p<0.01 ;{ }^{*}=p<0.05 ; \mathrm{ns}=$ not significant at $(p \leq 0.05)$.

Table 4: The number of pods, pod length $(\mathrm{cm})$ and pod weight $(\mathrm{g})$ of three different varieties of yard long bean cultivated with an area of $4 \mathrm{~m}^{2}$ under different growing conditions.

\begin{tabular}{|c|c|c|c|}
\hline & Number of pods & Pod length & Pod weight \\
\hline \multicolumn{4}{|c|}{ Wet season } \\
\hline Dark Green CLS614 & $148 \pm 13.5^{b}$ & $39.5 \pm 0.75^{b}$ & $10.1 \pm 0.70^{b}$ \\
\hline Jin Shan CLS615P & $227 \pm 19.4^{a}$ & $47.0 \pm 1.21^{\mathrm{a}}$ & $18.4 \pm 0.60^{a}$ \\
\hline Dark Green CSR024P & $159 \pm 16.2^{b}$ & $39.8 \pm 1.03^{b}$ & $9.92 \pm 0.57^{b}$ \\
\hline \multicolumn{4}{|c|}{ Wet-dry season } \\
\hline Dark Green CLS614 & $136 \pm 12.5^{b}$ & $40.0 \pm 0.30^{b}$ & $10.0 \pm 0.21^{b}$ \\
\hline Jin Shan CLS615P & $188 \pm 16.3^{a}$ & $42.2 \pm 0.13^{a}$ & $13.9 \pm 1.33^{a}$ \\
\hline Dark Green CSR024P & $141 \pm 9.39^{b}$ & $39.6 \pm 0.77^{b}$ & $9.37 \pm 0.56^{b}$ \\
\hline \multicolumn{4}{|c|}{ Dry season } \\
\hline Dark Green CLS614 & $129 \pm 1.29^{b}$ & $38.5 \pm 0.70^{b}$ & $11.7 \pm 0.85^{b}$ \\
\hline Jin Shan CLS615P & $142 \pm 2.36^{\mathrm{a}}$ & $44.0 \pm 0.57^{a}$ & $20.9 \pm 0.32^{a}$ \\
\hline Dark Green CSR024P & $129 \pm 1.03^{b}$ & $38.6 \pm 0.39^{b}$ & $13.6 \pm 0.80^{b}$ \\
\hline \multicolumn{4}{|c|}{ Significance } \\
\hline Growing condition (GC) & $* *$ & * & $* * *$ \\
\hline Genotype (G) & $* * *$ & $* * *$ & $* * *$ \\
\hline $\mathrm{GC} \times \mathrm{G}$ & ns & ns & ** \\
\hline
\end{tabular}

Values are mean $\pm \operatorname{SE}(n=12)$.

Means in the same column, followed by a different letter(s), are significantly different $(p \leq 0.05)$.

${ }^{* * *}=p<0.001 ;{ }^{* *}=p<0.01 ;{ }^{*}=p<0.05 ; \mathrm{ns}=$ not significant at $(p \leq 0.05)$. 
The results for pod length and pod weight showed a similar trend. For pod length, the results of Trial 1 , Trial 2 and Trial 3 indicate that the pod length was significantly the highest in the JS15P variety of yard-long bean. At the same time, no significant differences were observed in the pod length among the DG14 and DG24P varieties of yard long bean. For pod weight, the results of Trial 1 , Trial 2 and Trial 3 indicate that the pod weight was significantly the highest in the JS15P variety of yard-long bean. At the same time, no significant differences were observed in the pod weight among the DG14 and DG24P varieties of yard long bean. In all three trials, the JS15P had the highest pod length as well as the pod weight. No significant differences were observed in the pod length and pod weight among the DG14 and DG24P varieties. The two-way ANOVA results (Table 4 ) indicate that this could be due to the growing conditions or the genotype. However, for the pod weight, the interaction between the growing condition and the genotype could also be a factor.

\section{CONCLUSION}

The current study statistically showed that the growing conditions had minute effect on the growth of the yard-long bean plants; however, the genotype had the most effect. As for the yield, both the environmental conditions as well as the genotype had a significant effect. The highest yield and the better growth performance were observed in the JS15P variety of yard-long bean regardless of the growing condition; therefore, the JS15P variety of the yard-long bean is highly recommended to farmers in Fiji or recommended for cultivation in tropical conditions for higher yield. However, for small backyard farming or farming for personal consumption, all three varieties of yard-long bean can be used as the focus is not always on increasing the final yield.

\section{REFERENCES}

Anten, N.P.R. and Ackerly, D.D. (2001). A new method of growth analysis for plants that experience periodic losses of leaf mass. Functional Ecology. 15: 804-811.

Attia, R.H. and Sary, D.H. (2021). Effect of some soil conditioners on snap bean growth yield and sandy soil properties. Journal of Soil Sciences and Agricultural Engineering. 12: 123-129.

Bausch, W.C. and Diker, K. (2001). Innovative remote sensing techniques to increase nitrogen use efficiency of corn. Communications in Soil Science and Plant Analysis. 32: 1371-1390.

Brown, R.H. (1984). Growth of the Green Plant. In: Physiological Basis of Crop Growth and Development, [(Edn.) M.B. Tesar,], The American Society of Agronomy, Inc. and the Crop Science Society of America, Inc., Madison. pp.153174.

Cantwell, M.I. and Kasmire, R.F. (2002). Handling Systems: Flower, Leafy and Stem Vegetables. In: Postharvest Technology of Horticultural Crops, [(Edn.) A.A. Kader], University of California, Agriculture and Natural Resources Publication 3311, Oakland. pp 423-432.
Dharmawan, A., Suhadi, S. and Shodiqoh, H. (2021). Analysis of Cyanide Uptake (CN) and Growth of Yardlong Beans (Vigna unguiculata) with Different Planting Media Variations and Planting Periods of Sekotong People's Gold Mining Soil Sediment. International Conference on Life Sciences and Technology (ICoLiST 2020), Indonesia, AIP Conference Proceedings, DOI: doi.org/10.1063/5.0052788.

Eboibi, O., Akpokodje, O.I. and Uguru, H. (2018). Growth performance of five bean (Phaseolus spp) varieties as influenced by organic amendment. Journal of Applied Sciences and Environmental Management. 22: 759-763.

Fageria, N.K., Baligar, V.C. and Clark, R. (2010). Physiology of Growth and Yield Components. In: Physiology of Crop Production, CRC Press, Boca Raton. pp. 61-94.

Fiji Meteorological Service (2015). Current and future climate of the Fiji Islands. Pacific-Australia Climate Change Science and Adaptation Planning Program.

Fiorentini, M., Zenobi, S., Giorgini, E., Basili, D., Conti, C., Pro, C., Monaci, E. and Orsini, R. (2019). Nitrogen and chlorophyll status determination in durum wheat as influenced by fertilization and soil management: Preliminary results. Plos One. 14(11): e0225126.

Fontes, P.C.R. and de Araujo, C. (2006). Use of a chlorophyll meter and plant visual aspect for nitrogen management in tomato fertigation. J. Appl. Hort. 8: 8-11.

Fraile-Robayo, R.D., Álvarez-Herrera, J.G., Reyes, M.A.J., ÁlvarezHerrera, O.F. and Fraile-Robayo, A.L. (2017). Evaluation of the growth and quality of lettuce (Lactuca sativa L.) in a closed recirculating hydroponic system. Agronomía Colombiana. 35: 216-222.

Godfray, H.C.J., Beddington, J.R., Crute, I.R., Haddad, L., Lawrence, D., Muir, J.F., Pretty, J., Robinson, S., Thomas, S.M. and Toulmin, C. (2010). Food security: The challenge of feeding 9 billion people. Science. 327: 812-818.

Hatfield, J.L. and Prueger, J.H. (2015). Temperature extremes: Effect on plant growth and development. Weather and Climate Extremes. 10: 4-10.

Islam, M.A., Boyce, A.N., Rahman, M.M., Azirun, M.S. and Ashraf, M.A. (2016). Effects of organic fertilizers on the growth and yield of bush bean, winged bean and yard long bean. Brazilian Archives of Biology and Technology. 59. https:// doi.org/10.1590/1678-4324-2016160586.

Lemi, T. and Hailu, F. (2019). Effects of climate change variability on agricultural productivity. Int. J. Environ. Sci. Nat. Resour. 17: 14-20.

Li, Y., He, N., Hou, J., Xu, L., Liu, C., Zhang, J., Wang, Q., Zhang, $X$. and $\mathrm{Wu}, \mathrm{X}$. (2018). Factors influencing leaf chlorophyll content in natural forests at the biome scale. Frontiers in Ecology and Evolution. 6: 64.

Ministry of Communication (2021). Hon. Dr. Mahendra Reddy's Launching Statement at Ra Farm (Bainisoqosoqo Junction). The Fijian Government, Fiji.

Nastis, S.A., Michailidis, A. and Chatzitheodoridis, F. (2012). Climate change and agricultural productivity. African Journal of Agricultural Research. 7: 4885-4893.

Nausori Town Council (2021). Weather and Climate. Nausori Town Council, Fiji. 
Peng, S., Garcia, F.V., Laza, R.C., Sanico, A.L., Visperas, R.M. and Cassman, K.G. (1996). Increased N-use efficiency using a chlorophyll meter on high-yielding irrigated rice. Field Crops Research. 47: 243-252.

Piekielek, W.P., Fox, R.H., Toth, J.D. and Macneal, K.E. (1995). Use of a chlorophyll meter at the early dent stage of corn to evaluate nitrogen sufficiency. Agronomy Journal. 87: 403-408.

Rai, A., Sharma, V. and Heitholt, J. (2020). Dry bean [Phaseolus vulgaris $\mathrm{L}$.] growth and yield response to variable irrigation in the arid to semi-arid climate. Sustainability. 12: 3851.

Raihan, M.S.H., Islam, M.S., Islam, M.M., Khan, R.N.A. and Hossain, B. (2021). Impacts of organic and inorganic fertilizers on growth and yield of country bean (Lablab purpureus L.) in summer season. Bangladesh Journal of Multidisciplinary Scientific Research. 3: 1-9.

Rana, M.K. and Yadav, N. (2018). Yard Long Bean. In: Vegetable Crop Science, [(Edn.) M.K. Rana], CRC Press, Taylor and Francis Group, Boca Raton. pp. 805-813.

Sakthivel, S., Renugadevi, J., Raja, K. and Swarnapriya, R. (2020). Assessing the pattern of seed development and maturation in yard long bean [Vigna unguiculata subsp. sesquipedalis (L.) Verdcourt]. Legume Research. DOI:10.18805/LR-4378.

Schneider, J., Thiesen, L., Engroff, T., Holz, E. and Altíssimo, B. (2018). Growth analysis of lettuce under different substrate compositions. Advances in Horticultural Science. 32: 221-227.
Sharma, T., Singh, J. and Kaur, N. (2021). Effect of organic sources of nutrients on growth and growth indices of cowpea (Vigna unguiculata) under mid hill conditions of Himachal Pradesh. Himachal Journal of Agricultural Research. 46: 201-204.

Sheaffer, C.C. and Moncada, K.M. (2011). Plant Physiology and Growth. In: Introduction to Agronomy: Food, Crops and Environment (2 $2^{\text {nd }}$ Edn.). Cengage Learning, New York. pp. 177-197.

Suma, A., Latha, M., John, J.K., Aswathi, P.V., Pandey, C.D. and Ajinkya, A. (2021). Chapter 8-Yard-long bean. In: The Beans and the Peas, [(Edn.) A. Pratap and S. Gupta], Charlotte Cockle, Cambridgeshire. pp. 153-172.

Sundar, L.S. and Chen, G.S. (2020). Study on the growth performance of lettuce (Lactuca sativa) and pak choi (Brassica chinensis) in different aquaponic growing systems. Horticulturae. 6: 69.

United Nations (2019). World Population Prospects 2019: Highlights (ST/ESA/SER.A/423). Department of Economic and Social Affairs, Population Division, New York.

Xiong, D., Chen, J., Yu, T., Gao, W., Ling, X., Li, Y., Peng, S. and Huang, J. (2015). SPAD-based leaf nitrogen estimation is impacted by environmental factors and crop leaf characteristics. Scientific Reports. 5: 13389. 